\title{
THE POSITION OF SOKOBANJA ON THE TOURIST MARKET OF SERBIA
}

\author{
Aleksandar R. Radivojević ${ }^{* 1}$ \\ "University of of Niš - Faculty of sciencies and mathematics, Niš
}

\begin{abstract}
The aim of the paper is to define the significance of natural and anthropogenic tourist values of Sokobanja and to point out its analysis of the material base of tourism in its overall position and especially in the spa tourism of Serbia. The richness of natural values and favorable geographical position conditioned the development of the spa spa in the initial period of development, while the anthropogenic resources were activated as a supplement to the total tourist offer. The main tourist resource, around which the brand and image of Sokobanja is being built, are thermo-mineral resources. An analysis of the number of tourists and tourist nights indicates the tendency of reducing the average number of overnight stays. Particularly prominent is the example of foreign tourists who stay on average only slightly more than 2 days, which indicates the transitability of this area and the fact that Sokobanja is not the final destination for these tourists.
\end{abstract}

Key words: Sokobanja, thermo-mineral springs, material base of tourism.

\section{Introduction}

Spa tourism is one of the most important motive forms of movement based on the richness of natural and anthropogenic tourist values. As places with preserved and healthy environment, spas always have attracted attention of tourists and researchers. Research in spa tourism has a long tradition in European research framework. At the beginning of the twentieth century, almost

${ }^{1}$ Corresponding author: A. R. Radivojević, University of Niš - Faculty of sciencies and mathematics, Višegradska 33, 18,000 Niš, Serbia; e-mail: a.radivojevic@yahoo.com 
all research was based on the possibilities of using a medicinal factor. However, later studies contained in Alina-Cerasel (2015), Draghici et al (2015); Bakucz \& Köbli (2016); Roanghes-Mureanu \& Tudorica (2014) called for the addition of a health spa to provide the opportunity for the development of other forms of recreational tourism. Their studies were closely related to the possibilities of developing wellness and spa tourism. The development of wellness and spa tourism, as special forms of tourism, positioned the spa among the most important tourist destinations. Significant researches on (re)positioning of the spa on the tourist market were carried out in works by Fontanari \& Kern (2003).

Also, in the Republic of Serbia, the question of the development of spa tourism were treated in many scientific works. Qualitative and quantitative research in the field of health tourism and the economic significance of the spa in the overall tourism of Serbia was carried out by the authors: Костић(1974, 1977, 1978, 1981), Станковић (2002; 2005, 2006, and others), Јовичић Д. $(2008,2009)$. Contemporary research that is intensifying at the beginning of the $21^{\text {st }}$ century is more closely related to the analysis of the quality of accommodation capacities and the quality of services in the spas. The analysis of the quality of hotel services has been carried out by Blesic et al. (2014), while the historical development of spa tourism was analyzed by Armenski et al. (2009). In almost all works, the conclusion is that the Republic of Serbia is a country of spas, and that there is more than a favorable attractive potential for the development of this motive of the movement.

With over 300 thermo-mineral springs, the Republic of Serbia has a relatively high potential for the development of spa tourism. Thermo-mineral resources are spread across the entire territory of the country, and somewhat more concentrated in the wider area of Pomoravlje (South and Great). The attractive potential for the development of spa tourism, besides thermal springs, is also found in the richness of anthropogenic tourist values. They are a result of the long and tumultuous history, but also of the significant continuity of the spa settlement in Serbia. Almost all spas in the Republic of Serbia have been intensively used since the Romans. Significant expansion, both in terms of the use of the healing factor, as well as in terms of population, is given to the spa towns by the Turks. In recent history, the greatest progress in the development of spa, and hence the development of spa tourism, has been linked to the period since the Second World War. In the seventies and eighties of the twentieth century, in most of the spa, intensive construction of accommodation capacities and accompanying tourist infrastructure and suprastructure began. Certain spas in Serbia then become a significant factor in the overall tourism of Serbia, and among them is especially Sokobanja. 
Significant natural and anthropogenic tourist motives of Sokobanja distinguished this place as one of the most important spas in the Republic of Serbia. About 200,000 tourist nights in Sokobanja Municipality per year, positioned it at the very top of spa resorts in the Republic of Serbia. Among the spas of Serbia, a greater number of overnight stays were achieved only in Vrnjacka Banja. In the period 2000-2015. the total number of tourists in Sokobanja ranged between 40,000 and 67,000 . These tendencies point to the relative importance of Sokobanja in the overall tourism, and high importance in the spa tourism of Serbia.

Sokobanja municipality, is located in the central part of Eastern Serbia, about $60 \mathrm{~km}$ from Niš and $80 \mathrm{~km}$ from Zajecar. The territory of the Municipality encompasses the morphological unit of the Sokobanja basin, bounded by the mountains of Rtanj in the north, Ozren and Devica in the south, southeast and east, as well as Rožanj and Bukovik in the west and southwest.

Morphologically isolated, Sokobanja basin is connected with the major traffic routes (Pomoravski and Timočki) by regional road Aleksinac - Sokobanja - Knjaževac. This way, the Municipality has enabled taking the road route E-75, the main trajectory of the movement of tourist flows through the Republic of Serbia. The another regional route connecting Sokobanja with Knjaževac municipality, enables the connection with the cities of East Serbia, Negotin and Bor.

The position of the Municipality of Sokobanja to the major centers of tourism demand is relatively favorable. In the gravity zone of a road distance of up to $100 \mathrm{~km}$, there are urban centers such as: Niš, Knjaževac, Paraćin, Aleksinac and Zaječar. In the second zone of gravitation of Sokobanja (100$200 \mathrm{~km}$ ) there are centers: Negotin, Požarevac, Leskovac, while the most important domestic outbound centers: Belgrade and Novi Sad are located in the third gravity zone at a distance of $201-500 \mathrm{~km}$.

\section{Methodological framework}

Considering the set goal of the research, various methods have been applied in the paper. In addition to standard tourism-geographic, comparative method and methods of analysis and synthesis were used. The research work itself required the use of available literature and data from the Republic Institute for Statistics. As additional methods, the results of different surveys of tourists in the period 2000-2015 were used, as well as data obtained during long-term field research. 


\section{Tourist resource base and discussion}

The total tourist potential of the Municipality of Sokobanja has been presented with numerous natural and anthropogenic motifs. Among them, the most important are certainly healing medicinal thermal waters with specific balneological properties as well as potentials for the development of rural, ecological, congress and cultural tourism. With such a resilient basis and long tradition in the realization of tourist activities, Sokobanja represents a tourist center and an economic pole of the development of a wider area.

Thermominer sources, a favorable climate, a great dissection of the relief and the presence of a mountain environment represent the primary resources that motivate tourists to visit Sokobanja.

The occurrence of thermo-mineral wellsprings is due to the morphotectonic complex of the Sokobanja basin. At the very bottom of the basin and along the periphery of the basin, as many as six cleavages were identified: Sokobanja, Ozren, Sesalac, Cleavage of Gola planine, Rtanj and Poružnica. The appearance of thermo-mineral springs is primarily related to Sokobanjski rased, while many other thermal springs are located along the Moravica stream.

The development of the health-care function of Sokobanja has a long tradition. Even the Romans knew the benefits of these waters. Warm water has been exploited to a large extent during the period of the Turks empire, while modern development of the spa begins after 1835, when the first chemical analyzes of water were carried out. According to Протић (1995) and Станковић (2000), water is characterized by increased radioactivity and mineralization. In terms of hydrogeological reonization of the Sokobanja basin, this springs belong to the Karapato-Balkanida region.

In the spa complex there are six thermal springs of water with different chemical and thermal characteristics. A wellhead "Park" is the main thermal spring. The water that emerges in the old capta at the place of the old bathroom, is a neutral character in terms of ph value. In the area of the old bathroom the so-called Milošev konak, in the central city core is the source "Preobraženje". On the left river bank of the Moravica, there are two other sources: "Banjica 1" and "Banjica 2", while the source "Lepterija" is located on the right river bank in the same river. In the surroundings of the spa park there is the source "Moravica" (Радивојевић i dr, 2010).

The mountain hinterland of the basin and specific morphological features give opportunities to activate special recreational tourism activities. In 
addition, the neighboring mountain environment provides the possibility of a complementary development of mountain and spa tourism. The mountains that are important for the development of tourism are above all: Rtanj, Ozren and Devica. The most valuable mountain is the Rtanj mountain, which rises above $1523 \mathrm{~m}$ above the northern part of the Sokobanja basin. This mountain represents a potential tourist resource for the development of winter tourism, excursion and recreational tourism.

A specific touristic motive is also the Sesalic Cave. The typical tunnel cave, through which Zarvina River has been stream, is located in an ecologically preserved natural environment, representing a touristic motive in which speleoturism can be activated.

The development of tourism is encouraged by favorable climatic conditions of Sokobanja. Extremely favorable climatic features are distinguished by air temperature, moderate precipitation and sufficient amount of sunshine insulation, giving this place the character of the health resort (air spa). The mean annual air temperature is $10.29^{\circ} \mathrm{C}$. The coldest month of January has an average temperature of $-1.25^{\circ} \mathrm{C}$, while the warmest month is July with a mean temperature of $21.4^{\circ} \mathrm{C}$. The average number of days in the year with air temperatures above $18^{\circ} \mathrm{C}$, which is suitable for tourist movements and is considered a tourist season, is 92 days in the Sokobanja basin (Радивојевић, 2008).

The wealth of Sokobanja is reflected in the possibility of complementary use of natural tourist motives. The integration of tourist motives into tourist clusters would greatly complement Sokobanja tourist offer. Activating the mountain environment, directing tourists to sports and recreational activities are just some of the ways in which Sokobanja needs to plan the future development of tourism.

The long-term population of the Sokobanja Municipality is reflected in the preserved numerous objects of material culture. These objects can be classified as the remains of cultural, historical and archaeological heritage that have certain tourist potential. Anthropogenic tourist motifs that stand out especially are Sokograd and Turkish bath "Amam".

Sokograd represents a fort in the southeastern part of the Sokobanja ba$\sin$. The fortress was originally built by the Romans in the first century BC, consis of two parts: the Lower and Upper Town. In the upper town there are the remains of former towers that were used for defense and a firewall with cannon holes. In this part of town was a water tank. The lower town is characterized by a specific petangular shape with two domes. The entire complex of 
Sokograd is under the protection of the state as a cultural monument of national importance. The high attractiveness of this area is also provided by the very position on the edge of the Moravica gorge in an ecologically preserved ambience called "Lepterija". In addition to this fortification in Sokobanja, there are other objects from the ancient period as well as Roman castles, of which: Latin city, Trubarevac fort, Rujevica, Tatomir fort and Lipa fort (Радивојевић, 2008).

From complex anthropogenic motifs, stands out Turkish bath "Hamam". Of the objects of material culture of importance for tourism, there are also the following: Monastery Sv. Archangel, Orthodox Church of Sv. Preobraženja Gospodnjeg and the building of the Miloš Konak.

In addition to cultural and historical monuments, anthropogenic tourist motives include cultural and tourist events. They are events of local or regional importance. Events take place during the summer season, ie. „spa cultural summer", and they are striving to complete the tourist offer. The manifestations that emerge are: the musical character ("First Accordion of Serbia“), the folk creativity (",Golden Hands") or are directed to staying in nature and gathering medicinal herbs („,St. John Biljober"). In order to preserve these events from oblivion, work on their promotion and higher level of involvement of them in the overall tourism offer of the municipality is necessary.

\section{Accommodation facilities}

Development of basic and complementary accommodation receptive in Sokobanja can be monitored since 1932, when the first villa of commercial type was built. The development of the spa resort after the Second World War caused the intensive construction of the settlement and the raising of new accommodation capacities, so that in Sokobanja in 1960. there were about 280 beds arranged in nine villas. The golden age of the construction of Sokobanja is related to the period of its greatest visit, 1975-1985. year, when all six hotels were built, and day are still in function. Today Sokobanja has around 15,000 beds distributed in buildings of different categories. The material base of tourism is characterized by the disproportion between basic and complementary capacities, which are in the ratio of 90: 10\% in favor of complementary ones. The most important facilities for accommodation of tourists were hotels: "Zdravljak" built in 1979. with 540 beds, "Moravica" with 200 beds, "Banjica" with 280 beds and "The Sun" which has 260 beds. All hotels are equipped with a variety of sports facilities, swimming pools and recreational facilities, which encourage the development of sports and 
recreational tourism. Hotels also have congress hall, and offer opportunities to activate a business or congress tourism.

A special category of total accommodation capacities are Bureau on Ozren and Special hospital Sokobanja availing of 580 beds.

\section{Changes in the number of tourists}

One of the most important indicators of tourism development in spas (but also other tourist destinations) is tourist traffic. Valorization of tourist motives in Sokobanja is reflected in the increased concentration of domestic tourists. According to the total annual tourist traffic, Sokobanja is located in second place, just behind Vrnjacka Banja. According to the significance of Sokobanje in the total tourism turnover achieved in the Spas of Serbia, Јовичић (2008) classified it in the first group of spas.

The development of organized tourism in Sokobanja relates to the period of the first half of the $19^{\text {th }}$ century, i.e. year 1837. In the period between the two world wars, the tourist visit in Sokobanja was quite high for this period. The number of guests in 1933. amounted to 1,566, with a total of 22,265 overnights. A strong tourist development with a large number of Sokobanja arrivals records after the Second World War. The number of registered tourists has grown steadily from year to year, reaching 34,000 tourists in 1970. The 1970-1980. period is characterized by an increase in the number of tourists whose number ranges between 34,000 and 69,000 in 1979. The period of the most intensive development of the spa has started since 1980. and lasted until 1988. In the mentioned period, the number of tourists ranged from 55,000 to the maximum reached in 1987 . when it was 97,901 . The period after that is characterized by a decline in the number of visitors, so that by the beginning of the $21^{\text {st }}$ century Sokobanja visited between 28,000 and 64,000 annually. The structure of visitors throughout the observed period showed a pronounced anomaly and a lack of foreign tourists. The share of foreigners in the total number of tourists until 2005. was negligible. Foreign tourists participated with less than $1 \%$ in total tourist traffic until 2000. Modern trends show a change, and in 2015. the share of foreign tourists was $12 \%$.

The analysis of the number of overnight stays in Sokobanja shows the tendency to shorten the stay of tourists. While the average number of overnight stays in the period 1975-1985 amounted to over 10, at the beginning of the $21^{\text {st }}$ century it was reduced to about 6 nights. According to the data 
from 2015, the average retention of tourists in Sokobanja is 4.6 days. Domestic tourists stay on average for 5 days while foreigners stay on site only 2.4 days. These tendencies can be interpreted in two directions. Reducing the stay of tourists is a consequence of the change in the motive of a visit to the spa. In the past, tourists visited Sokobanja primarily for health reasons and for the development of some postoperative course, for which a period of as much as 21 days was recommended, which required a longer stay of visitors. However, modern tendencies show that tourists visit Sokobanja primarily for preventative reasons or are motivated by the tourist offer of the spa itself, which leads to a shortening of tourists' sojourn.

Table 1 - Tourist visit in Sokobanja in period 1970 - 2015

\begin{tabular}{|c|c|c|c|}
\hline \multirow{2}{*}{ Year } & \multicolumn{2}{|c|}{ Toursits } & \multirow{2}{*}{ Total } \\
\cline { 2 - 3 } & Domestic & Foreign & \\
\hline 1970 & 34,000 & 146 & 34,146 \\
\hline 1975 & 44,642 & 189 & 44,831 \\
\hline 1980 & 55,519 & 256 & 55,775 \\
\hline 1985 & 67,500 & 893 & 68,393 \\
\hline 1990 & 56,015 & 487 & 56,502 \\
\hline 1995 & 39,436 & 134 & 39,570 \\
\hline 2000 & 65,434 & 840 & 66,274 \\
\hline 2005 & 66,512 & 1,087 & 67794 \\
\hline 2010 & 47,572 & 1,265 & 48,837 \\
\hline 2015 & 37,154 & 4,522 & 41,676 \\
\hline
\end{tabular}

Source: Data from Republic Institute for Statistics

\section{Conclusion}

The position of Sokobanja in the overall tourist traffic of Serbia, it seems not great. The share of tourists visiting the spa is only $2 \%$ of the total number of visitors to Serbia. Still, the position of the spa in relation to spa tourism is to a great extent different. Sokobanja absorbs almost $15 \%$ of all tourists visiting the spa in Serbia, which places it in a different place according to importance among the spas.

Sokobanja is characterized by significant natural values that represent a strategic resource in the development of tourism, but also the overall economic progress of the Municipality. Dominant touristic motives are 
thermo-mineral resources whose primary importance is the development of health-spa tourism. In addition to thermal waters, Sokobanja basin is distinguished by the mountain hinterland where Rtanj stands out, which favors the development of winter, sports and recreational and excursion tourism. These benefits, accompanied by favorable climate characteristics, give a good resource base for Sokobanja.

Analysis of tourist traffic realized in the period 1970-2015. point to certain principles. The changes of the number of tourists in Sokobanja have been influenced by number of economic, political and other factors. The maximum number of visitors to Sokobanja was realized in 1987. when 94,901 visitors were registered. The minimum tourist recorded, was achieved at the beginning of the observed period - 1970 (34,000 tourist visits). Sokobanja is characterized by strongly developed domestic tourism. Until the beginning of the $20^{\text {th }}$ century almost all tourists were from Serbia, while foreign tourists were negligible and their share was around $1 \%$. After 2000, the situation has been partially corrected and in 2015. the share of foreign tourists makes up $12 \%$. There are tendencies of short stay of domestic and foreign tourists. This phenomenon is the result of a change in the motives for tourists visiting the spa. The second half of the $20^{\text {th }}$ century is characteristic of the visits of patients who came to Sokobanja on a postoperative course that once lasted for 3 weeks. In the period 1970-1985. The length of stay of the tourists lasted 11 days. Now, this stay is shortened to 5 days. Tourists come on an extended weekend to preserve preventive health above all. Also, the analysis of the length of retention of domestic and foreign tourists indicates some disproportion. While domestic tourists stay on average for 5 days, foreign tourists limit their stay to 2.4 days. This proves the assumption that foreign tourists are in transit and that Sokobanja is not their primary destination.

The future development of tourism in the territory of the Municipality of Sokobanja should be directed towards achieving full complementarity of natural and anthropogenic tourist values and to organize a specific tourist cluster Sokobanja. This would complement the existing tourist offer and encourage the development of other activities. By redirecting to selective, profitable and quality tourist programs, the working contingent of the younger working age population would be engaged, which would influence the prevention of the process of depopulation of the Municipality. Strategic planning of tourism development should include rural settlements and connect them with the municipal center to better road infrastructure. The task of the tourist organization of the Municipality and other relevant associations is the strengthening of human resources and capacities, conducting trainings and education related to 
the organization and implementation of tourist activities. In this way Sokobanja would stand out as a kind of pole of the development of the Zaječarski district and would ensure its better positioning on the tourist map of Serbia.

\section{Acknowledgements}

The paper is the result of the research within the project no. 176008 funded by the Ministry of Education and Science of the Republic of Serbia.

\section{References}

Alina-Cerasela A. (2015). Spa tourism - A comparative analysis on Spain and Romania. Balneo research journal, 6(3): 199-207. http://dx.doi. org/10.12680/balneo.2015.10106

Armenski T., Blešić I., Djeri L., Dragin A. (2009). Historical development of health and spa tourism in Serbia. 14th International Conference of Historical Geographers, Kjoto University. Congress Proceedings.

Bakucz M., Köbli A. (2016). A competitive analysis of spa tourism in Central European regions. Tourism E Hospitality Industry 2016, Congress Proceedings, pp. 1-17

Blešić I., Popov-Raljić J., Uravić L., Stankov U., Djeri L., Pantelić M., Armenski T. (2014). An importance-performance analysis of service quality in spa hotels. Economic research, 27(1), 483-495.

Draghici C.C., Pintilii R.D., Perptenatu D., Comanescu L.G., Sirodoev I. (2015). The Role of SPA Tourism in the Development of Local Economies from Romania. Procedia Economics and finance 23, 1573-1577. doi: 10.1016/S2212-5671(15)00400-1

Fontanari M. \& Kern A.(2003). The Comparative analysis of spas" - An instrument for the re-positioning of spas in context of competition in spa and health tourism. Tourism review, 58(3): 20-28. https://doi.org/10.1108/eb058413

Jovičić D., Hrabovski-Tomić E. (2009). Potentials for tourism development in Serbia's spas. in: 4th International Scientific Conference, Planning for the future learning from the past: Contemporary Developments in Tourism, Travel \& Hospitality, Greece, University of the Aegean, [online], Accessed 15 Jun 2014

Pavlović M., Radivojević A., Dimitrijević Lj (2011). Climate of Sokobanja basin and its influence on development and agriculture, Journal of Geographical institute "Jovan Cvijić" SASA, 61(1), 13-30. 
Roanghes-Mureanu A.M., Tudoricu A. (2014). Development opportunities for spa tourism in Vâlcea Subcarpathians: Towards a single European market. Human Geographies - Journal of Studies and Research in Human Geography, 8(2), 111-123. DOI: 10.5719/hgeo.2014.82.111

Јовичић Д.(2008). Стање и перспективе развоја бањског туризма у Србији. Гласник Српског географрског друштва, 88(4), 3-17.

Костић М. (1974). Термална налазишта и важнија бањска места Источне Србије. Зборник радова Географског института Јован Цвијић, 25, 105-173.

Костић М. (1977). Корачића бања. Зборник радога Географског института Јован Цвијић, 29, 217-232.

Костић М. (1979). Рибарска бања. Зборник радога Географркког института Јован Цвијић, 30, 85-122.

Костић М. (1981). Бања Ковиљача. Зборник радога Географрског института Јован Цвијић, 31, 133-174.

Протић Д. (1995) : Минералне и термалне воде Србије. Геоинститут, Београд.

Радивојевић А. (2008). Туризам као фактор развоја Сокобање, Економске теме, 46(2), 111-129.

Радивојевић А., Филиповић И., Стричевић Љ., Гоцић М. (2010). Географске основе развоја туризма у Сокобањи. Гласник сриског географског друштва, 90(3), 111-125.

РЗС (2012). Општине и региони у Републици Србији. Републички завод за статистику. Београд 2012. Документациони материјал Републичког завода за статистику.

Станковић С. (2000). Туристичка географија. Географски факултет, Београд.

Станковић С., Јовановић В. (2006). Бање Србије и њихов значај за туризам. У Планирање, уређење и заштита банских и климатских места Србије, Географски факултет, АПП Србије, Београд.

Станковић С., Павловић С. (2005). Бањски и планински туризам Србије, Зборник радова - Географски фракултет Универзитета у Београду, 53, 75-90. 